\title{
BRAND REVITALIZATION: DON'T LET YOUR BRANDS TURN INTO SLEEPYHEADS
}

\author{
Kolbl, Ž., Konečnik Ruzzier, M., Kolar, T.
}

\begin{abstract}
Brand revitalization is a process, which is often necessary when the brand's offer of products as well as associated attention from consumers decline. Even so, the core of a brand needs to be clearly defined, in order for brand revitalization to be successfully implemented. Marketing managers need to be able to recognize the acute, as well as the latent signs of brand aging, and need to implement brand revitalization elements and strategies that are most suitable for a certain brand. The goal of the paper is presenting brand revitalization through the practical example of two Slovenian brands, which both went through the process of brand revitalization. With the review of secondary data, as well as interviews with the brand's marketing managers, the paper proposes main steps and serves as a guideline to other managers, when going through brand revitalization.
\end{abstract}

Keywords: revitalization; rejuvenation; brand aging; strategies of brand revitalization JEL classification: M31

\section{Introduction}

Brands get established, they grow, expand and are successful, or they wane in popularity with their users. Through the entirety of their existence in the market environment, brands are surrounded by other brands, with which they constantly compete for clients' affection. Is brand vitality synonymous with powerful brand names, or is vitality dependent on certain external conditions? Numerous brand managers who wish to sustain the successfulness of a given brand, very often encounter the problem of brand aging.

A brand is indeed considered to be of age as soon as it starts being neglected or shunned by the consumer (Aaker, 1991). So the question becomes the following: Can brand managers, through a revitalization process, reverse a brand's aging process and make it attractive to the consumer once again? The main purpose of this paper is to contribute to the area of brand revitalization, as one of the approaches to managing aging brands. Therefore we argue the importance of recognizing acute and latent signs of brand aging, the identification of revitalization elements and possible strategies of revitalizing the brand.

\section{Theoretical Background}

The definition of brand revitalization in professional literature is anything but consistent. Numerous authors (Zhang and Sun, 2009; Keller, 1999; Müller et al., 2013; Lehu, 2004) write about brand rejuvenation, which predominantly encompasses the idea of refreshing the visual aspects of a specific brand. With this in mind, we can claim that a change in the consumer's understanding of the brand is produced and thus, a change in the consumer-product relationship is achieved. Babu (2006) equates brand revitalization with 
brand rejuvenation and considers it a sort of revamping of a brand, a process which also encompasses the regeneration of the brand's identity. Kapferer (2008) molds and upgrades the definition of brand revitalization into a coherent whole. "Brand revitalization, in the narrow sense, consists of recreating a consistent flow of sales, putting the brand back to life, on a growth slope again. When the brand is made up of many products, we shall see that this typically entails two parallel actions: maintaining a well-known product globally in its original design and form (to keep its franchise) and reinventing it for new and younger consumers (that is to say asking the question, what would this product be today, if we had to invent it from scratch for the needs of modern consumers?)" (Kapferer, 2008, p.438). In combination with the previously mentioned elements of brand revitalization, the author also expresses the need for the rejuvenation of a brand's visual aspects, with the distinct purpose of maintaining and/or re-establishing the competitiveness of said brand. Brand revitalization therefore demands a re-establishment of the basic aspects of the brand, which includes a rejuvenation of the entirety of the brand's overall graphic design.

It quickly becomes apparent that the definition of brand revitalization in professional literature differs greatly from author to author. All of the previously mentioned authors agree on one thing though - the need to review the general state of the brand before attempting the revitalization process. It is important to confirm the reasonableness of intervening with a given brand, from a financial point of view, as well as the current positioning of the brand in the market place and its reputation (Haig, 2003). Lehu (2004) is of the opinion that brand managers must be able to recognize the signs of brand aging, specifically by paying attention to the product offer, targeted group of consumers and the brand's ability to communicate with its consumers.

In this paper we focus on three important elements of brand revitalization: the analysis of acute and latent signs of brand aging (Lehu, 2008); the identification of revitalizing elements (Lehu, 2008) and a range of different strategies for brand revitalization (McLellan, 2006; Simmons, 2006; Gobe, 2007; Morrison and Crane, 2007; Sherry and Kozinets, 2003).

According to Lehu (2008), we can differentiate between acute and latent signs of brand aging, according to their area of influence, that encompass three specific criteria: the brand's offer of products, the target group of consumers and the brand's ability to communicate with its clients. In the area of the brand's offer of products, are placed acute and latent signs of brand aging, which are intimately connected with research and development (i.e. slow launches of new products), the characteristics of the product (i.e. the correlation between promised and real-life results) and with the competitive standing of a brand (i.e. constant depletion of market share). The criteria of targeted groups of consumers is comprised of all acute and latent signs of brand aging, that are in one way or another connected with consumers (i.e. constant decline of customer loyalty). The last criteria, that of the brand's ability to communicate with its consumers, is composed of all signs of aging, that influence advertising (i.e. obsolete, unclear communication), corporate communication (i.e. the brand's reputation diminishes in the eyes of the public/consumers) and public relations of a brand (i.e. highly publicized negative situations involving the brand).

By using the above described methods to determine the latent and acute signs of brand aging, we can logically proceed to discovering elements, which are going to have a revitalizing effect on the said brand. For the purpose of attaining the best and most direct results, these elements should be incorporated into one of the long-term brand 
revitalization strategies. Elements of brand revitalization that influence the brand's external or visual aspect are re-inventing the identity of the brand, brand repositioning, innovative advertising, refreshing of the visual aspects of the brand and the expansion of the brand's portfolio of products.

The different strategies of brand revitalization may consist of emotional branding, retro-branding and storytelling. Storytelling, according to McLellan (2006), is one of the basic aspects of human intelligence and imagination, and is a powerful communication tool that requires complete attention and, more often than not, the listener's direct involvement. Simmons (2006) claims that storytelling gives brands and their products a personality and a deeper meaning.

Emotional branding indicates the establishment of a relationship between the consumer and the brand; it stems from the emotional and sensual levels and the end goal is a long-lasting, deep and meaningful connection between the two (Gobe, 2007). The importance of emotional branding, especially with service brands, is further solidified by Morrison and Crane (2007). All of the elements of emotional branding are potentially present in the customer's loyalty to a specific brand, which consequently influences the visibility of the brand and the success of its revitalization.

Retro-branding indicates a resurrection of specific attributes from the brand's past, attributes which are adapted to a more modern market place and the current aspirations of the consumer (Brown et al., 2003). In short, retro-branding means the returning of a brand into the market place with the use of certain revitalized elements of the brand's heritage (Brown et al., 2003).

\section{Research Methodology}

The purpose of this paper is the analysis of three important brand revitalization elements, using the example of two Slovenian brands. We decided on these two brands because they were both launched into the market place between 1950 and 1957, and are still present in the marketplace today. They both obviously survived the socialist era, when constant developmental work on brands was generally non-existent. In their lifetime, they survived many different periods, but lately it has become apparent that they have used some of the revitalization strategies that were described in the previous chapter by use of professional literature.

The first brand, Cockta, operates in the beverage market. Its product is known for its distinctive aroma of rose hip, being a unique blend of 11 different herbs, which it is devoid of caffeine and does not contain ortophosphoric acid. The drink is suitable for all generations of consumers and is based on values such as distinctiveness, quality, innovation and focus on nature. Together, with different variations of an original drink (cola drinks), the brand is retaining its high market position on the regional markets (Slovenia, Bosnia and Herzegovina, Croatia, Macedonia, Montenegro, and Serbia). In 2009, the market share of Cockta on the Slovenian market was 22\% (Coca-Cola was a market leader with 40\%) (Mohorč Kejžar, 2011). In 2014, the best results outside the region were achieved in Russia, Austria and Sweden. Moreover, the original drink was ranked among the best four cola drinks in the world by Times, meaning that it is a top product in global terms (Atlantic Grupa, 2014).

The second brand, Argeta, makes up part of the savory spreads/pâté market and is related to high-quality food product range. It is specifically recognized for its excellent 
taste and superior quality. The savory spreads/pâtés are made from the highest quality meats and prepared with all natural spices. The brand is composed of four different lines of product inside of the savory spreads/pâté products: original, junior, delight and exclusive line. The brand is present on the regional markets (Slovenia, Bosnia and Herzegovina, Croatia, Macedonia, Montenegro, Serbia), as well as on European markets (Austria, Germany, Switzerland, Italy, Sweden, UK, Ireland) and other export markets (Russia, Kosovo, Bulgaria, Albania, Canada, Australia, USA). The brand is a market leader in Slovenia, Bosnia and Herzegovina, Macedonia and Kosovo, and a number two in terms of market share in Croatia, Serbia, Montenegro, Austria and Switzerland with four of its products. Argeta's market share in 2011 was $42 \%$ in Slovenia, 24.6\% in Austria, 50\% in Bosnia and Herzegovina (Acnielsen, 2011). Further, the brand has an ownership of the following brand image elements in the region: best taste, good spreading, highest quality and trustworthiness (Atlantic Grupa, 2014).

Apart from analyzing the secondary data of the mentioned brands, we also invited both marketing directors, who are responsible for the brand's systematic development, to cooperate with us. With them, we performed an in-depth interview on the importance and method of revitalizing their respected brands. A part of the interview focused on the completion of a questionnaire about recognizing and evaluating latent and acute signs of brand aging (Lehu, 2004) of the two brands. The questionnaire was a steering guide for the in-depth interviews; the main criteria such as brand offer, target group and communication, were divided into sub blocks inside of each criteria. To each of the sub blocks we assigned different symptoms and signs of brand aging, which were later evaluated by marketing directors in the terms of danger, easiness, cost, time, and overall strategic decision.

\section{Results}

Careful analysis of the brands has shown that both marketing directors attribute more importance to those signs of brand aging that are the most intimately connected with the targeted groups of consumers. They both were also of the opinion that more importance should be placed into aging signs that express themselves through the offer of products and the brand's communication abilities. The marketing director of Cockta expressed that their revitalization strategy was based on presenting the quality of their product to the clientele, and that special emphasis was placed on signs of brand aging that were directly attributable to a specific product. Into this category, we can place aging inside the research and development department, while aging of the characteristics of the product and aging of advertisement and communication techniques are decisions made at the corporate level.

The marketing director of Argeta, however, was mainly focused on the level of consumer content, which is also reflected in a high importance given to signs of brand aging that are connected with the consumer aspects of a given brand. The acute and latent signs of brand aging are also, apart from the knowledge of marketing directors, inherently dependent on the personal style of brand management.

Concerning revitalization elements and revitalization strategies, we can claim that, in the case Cockta, several revitalization elements were used. Revitalization elements such as growth of the product portfolio (addition of more flavors of the classic soft drink), innovative advertising (use of creative illustrations) and a rejuvenation of the visual aspects 
of the brand (a change in the brand's slogan) were used by the brand. The revitalization strategy used by the brand can be said to be that of emotional branding, because what we are seeing is a direct and emotional approach to consumers. Just recently all of the drink's bottles have been made available in 50\% recycled plastics, a fact which corresponds to the brand's values. Moreover, the brand is still focused on growth of the product portfolio, which means that at least one revitalization element is still included in overall strategy. The revitalization strategy stays one of emotional branding, because with every further campaign they are keeping and emphasizing the emotional approach to consumers.

The second brand, Argeta, uses two very distinct revitalization elements - innovative advertising (very interactive concept, a choice of female candidates, moms, who later become the brand's ambassadors - "approved by moms") and a rejuvenation of the brand's visual aspects (a complete change in the way of communicating with consumers). The revitalization strategy used by Argeta can be said to be that of storytelling - through the use of the brand's ambassadors and their unique stories about the quality and excellence of the product. The brand has recently changed the whole packaging design and their marketing materials, meaning that they consistently work on one of the chosen revitalization elements - rejuvenation of the brand's visual aspects. The revitalization strategy of storytelling continues to be developed through the redesigned materials and overall brand communication. It is of an extreme importance to mention that the brand received one of the Euro Effie awards for effective marketing communications, i.e. for the mentioned campaign "approved by moms".

Further analysis of the interviews also exposes a couple of points of shared interest, as well as opposing approaches. The similarity between the two is best shown in the common understanding of the term revitalization, which both marketing directors understand as a strategic process, which is an indispensable part of a long-term brand strategy. At this point, we can draw a correlation with Kapferer's definition (2008). Both marketing directors were of the same opinion that the questionnaire on brand revitalization could contribute immensely to the insight and tracking of a brand's successes. They were both also of the opinion that market place surveys were one of the key activities that divulge the need of revitalizing a given brand.

The in-depth interview, combined with a relaxed conversation, also shed light on some subtle signs of expression which, together with the results of the survey, contribute to a completely personal approach to marketing of a brand. The marketing director of Cockta is a proponent of the shock principle, or as he expressed it, of "shock therapy", a quick and efficient response to changes in the market. He is of the opinion that the immediate implementation of changes is necessary and obligatory. The second marketing director, the one working for Argeta, swears on the principle of continuous work on a brand. He is focused on customer happiness; the brand's revitalization strategy is therefore customeroriented as well. He is a proponent of gradual implementation of changes. The results of the surveys could also be linked to their style of non-verbal communication that indirectly influences their respectful approaches to brand managing. Another contributing factor that influences the work of a marketing director is the dynamics of a specific market place in which a given brand or its product are a part. Both marketing directors, through their approaches and management styles, work in accordance with the market place where brands and their products are active participants. 


\section{Conclusion}

This paper examined the often overlooked and underestimated role of brand revitalization. In order to understand the situation in which the certain brand is, it is of the greatest importance to recognize the acute and latent signs of brand aging. With different revitalizing elements and strategies, which were examined through research, marketing managers are able not only to react, but take action to revitalize their brands. The selection of revitalization elements and strategies is also dependent on the personal style of brand management, as well as on specific characteristics of the market in which a certain brand takes part. It is important to emphasize that the use of revitalization elements which are carefully integrated into the revitalization strategy can lead to increased: market share (the brand that operates on savory spread market reports continuing growth on all markets), possibility of internationalization (both brands keep spreading their markets), strength of perceived brand image (reports), visibility of a brand in general (awards, communications). In conclusion, the three main brand revitalization steps are recognition of acute and latent signs of aging, implementation of revitalizing elements and the adoption of brand revitalization strategies.

Future surveys into brand revitalization could be made more comprehensive by including the opinions of the consumers and by analyzing the success of a brand's revitalization process. Surveys could consider including more brands, even though we have to be conscious that the number of brands that have gone through the revitalization process is in fact quite limited.

After reviewing numerous practical examples, it became quite apparent that brand revitalization is present specifically on the geographic area where countries have lived through Socialism (ex. former Yugoslavia). The revitalization process is therefore implemented on so-called socialist brands, which have a strong base that is synonymous with product quality and the quality of the ingredients used, but also with less consistent work on the brand. One of the reasons might be a less competitive market environment when compared with the global market. With bigger, more well-known brands, the revitalization processes, based on the models presented in this survey, were not as apparent. The process of brand revitalization can therefore be considered as an immediate measure of re-establishing the competiveness of the brand, especially if the work on the brand thus far has been unsuccessful or inconsistent. It is an obligatory measure when there is a wish to re-establish the brand's power, its visibility and other signs of its vitality. In these cases, we recommend to the applicable marketing directors that they make an analysis of the acute and latent brand aging signs and that, after completing the survey, they implement a combination of appropriate revitalization elements and strategies in order to revitalize their brand.

\section{References}

Aaker, D. A. (1991). Managing Brand Equity. New York: Free Press.

Acnielsen (2011). Argeta gre v Švici in Avstriji vse bolj v slast. Retrieved April 21, 2014 from http:// www.primorske.si/Slovenija-in-svet/Argeta-gre-v-Svici-in-Avstriji-vse-bolj-v-slast.aspx.

Atlantic Grupa (2014). Annual Report 2014. Retrieved April 20, 2014 from http://www.atlantic. $\mathrm{hr} / \mathrm{media} /$ files/fileitemtranslation/Godisnje-izvjece-2014/Annual\%20report\%202014.pdf.

Babu, V. (2006). Issues in Brand Rejuvenation Strategies. Retrieved April 10, 2013 from http:// www.expectad.com/white_paper/Brand_Rejuvenation_Expect_Advertising_Inc.pdf. 
Brown, S., Sherry Jr., \& J. F., Kozinets, R. V. (2003). Teaching Old Brands New Tricks: Retro Branding and the Revival of Brand Meaning. Journal of Marketing, 67(3), 19-33.

Gobe, M. (2007). Emotional Branding: The New Paradigm for Connecting Brands to People. New York: Allworth.

Haig, M. (2003). Brand Failures. Great Britain: Biddles Ltd, Guildford and King's Lynn.

Kapferer, J. N. (2008). The New Strategic Brand Management - Creating and Sustaining Brand Equity Long Term. London: Kogan Page Limited.

Keller, K. (1999). Managing Brands for the Long Run: Brand Reinforcement and Revitalization Strategies. California Management Review, 41(3), 102-124.

Lehu, J. M. (2004). Back to Life! Why Brands Grow Old and sometimes Die and What Managers then do: an Exploratory Qualitative Research put into the French Context. Journal of Marketing Communications, 1(2), 133-152.

McLellan, H. (2006). Corporate Storytelling Perspectives. The Journal for Quality and Participation, 29(1), 43.

Mohorč Kejžar, N. (2011). Prihodnost lokalnih blagovnih znamk brezalkoholnih gaziranih pijač. Retrieved April 20, 2014 from http://dk.fdv.uni-lj.si/magistrska/pdfs/mag_mohorc-kejzarnatasa.pdf.

Morrison, S., \& Crane, F. G. (2007). Building the Service Brand by Creating and Managing an Emotional Brand Experience. Journal of Brand Management, 14(5), 410-421.

Müller, B., Kocher, B., \& Crettaz, A. (2013). The Effects of Visual Rejuvenation through Brand Logos. Journal of Business Research, 66(1), 82-88.

Simmons, J. (2006). Guiness and the Role of Strategic Storytelling. Journal of Strategic Marketing, 14(1), 11-18.

Zhang, Y., \& Sun, M. (2009). Brand Rejuvenation of Old Food Enterprises Based on Combination of Innovation and Nostalgia. Retrieved April 20, 2013 from http://www.seiofbluemountain. com/upload/product/200910/2009glhy13a5.pdf

\section{Authors}

\section{Živa Kolbl, MBus.}

Young researcher and assistant

Department of Marketing

Faculty of Economics, University of Ljubljana, Slovenia

Kardeljeva ploščad 17, 1000 Ljubljana, Slovenia

ziva.kolbl@ef.uni-lj.si

\section{Maja Konečnik Ruzzier, Ph.D.}

Associate Professor

Department of Marketing

Faculty of Economics, University of Ljubljana, Slovenia

Kardeljeva ploščad 17, 1000 Ljubljana, Slovenia

maja.konecnik@ef.uni-lj.si

\section{Tomaž Kolar, Ph.D.}

Associate Professor

Department of Marketing

Faculty of Economics, University of Ljubljana, Slovenia

Kardeljeva ploščad 17, 1000 Ljubljana, Slovenia

tomaz.kolar@ef.uni-lj.si 